\title{
Tunneling through adverse geological conditions in granitic terrain
}

\author{
DS Rawat and AK Naithani \\ L G Singh,Prasanna Jainand Rajesh Patel \\ National Institute of Rock Mechanics, Bengaluru, India \\ dsrawat.nirm@gmail.com
}

\author{
K RavindraNath and RNS Babu \\ Aarvee Associates, \\ Hyderabad, India \\ suri2geo@gmail.com
}

\author{
G Srinivasa Rao and Khilap Singh \\ Navayuga Engineering Company Limited, \\ Hyderabad, India \\ khilapkunwar87@gmail.com
}

\begin{abstract}
Generally it is pre mind setup that granitic terrain is always suitable for tunneling media and requirement of detail feasibility studies are minimize accordingly. To facilitated irrigation and other utility en-route of seven draught prone Districts of Telangana State, Dr B R Ambedkar lift irrigation project is under construction. Twin tunnels $9.55 \mathrm{~km}$ length with $10 \mathrm{~m}$ finished dia are being constructed to lift water from SripadaYellampalli Reservoir to Medaram tank. Granitic rock with dominant intrusive zones of amphibolites/basic enclaves were observed in the studied tunnel length. Problematic zones categorized into fair, poor and very poor rock classes with occasional bands of good rock class based on rock tunneling quality index ' $Q$ ' between chainage 8.298 and $9.865 \mathrm{~km}$. This zone observed dripping to flowing in nature, created difficulties for tunneling. Heavy steel ribs were erected for rock mass supports in poor and very poor tunnel reaches as per design drawing. These problematic zones are responsible for delaying the construction progress and created vulnerable situation for the tunneling work.
\end{abstract}

Modifications /changes in excavations plan was done, which was very much essential as per the site condition to achieve the targeted quantity of excavation within the time frame. Intelligently changes in excavations were planned based on the anticipated poor rock masses at ahead of tunnels reaches. Modification was based on the subsurface exploration data. In this paper emphasis are made on the requirement of detailed feasibility study along the tunnel alignment even the tunneling media is made up of granite.

Keywords-granitic terrain; twin tunnels; sripadayellampalli reservoir; medaram tank; rock tunneling quality index

\section{I.INTRODUCTION}

The Dr.BR Ambedkar (Pranahitha - Chevella-SujalaShravanthi) Lift Irrigation Scheme is being constructed to lift 160 (TMC) water from the Pranahitha River $(\mathrm{EL}+150 \mathrm{~m})$ to the Chevella reservoir $(E L+635 \mathrm{~m})$. Pranahitha River is a tributary of Godavari River, which formed by the confluence of Wainganga and Wardha Rivers. The objectives of this scheme isto facilitate irrigation and other utility en-route for seven draughts prone Karimanagar, Khammam, Medak,
Nizamabad, Adilabad, Warangal and Ranga Reddy Districts of Telangana State.Package-6 of this scheme is being constructed to lift 146.24 TMC water from SripadaYellampalli reservoir to Medaram tank situated near DharmaramMandalin Karimnagar DistrictFig.1

The water need to be lifted from the tunnel bed level at $\mathrm{RL}+109 \mathrm{~m}$ to Medaram tank at its FRL $+230 \mathrm{~m}$. Twin tunnels $10 \mathrm{~m}$ finished dia and $9.55 \mathrm{~km}$ long are being constructed to supply the water with the design discharge of 535 cumecs. Twin tunnels will join the surge pool cavern, from where draft tube tunnels lead to the pump house cavern is being constructed. Underground cavernswere planned because it is safer construction, more economic and environmental friendly.

Water will be lifted from RL $109 \mathrm{~m}$ to the cistern located at ground level RL $+241 \mathrm{~m}$ with the help of pumps and through pressure/delivery mains. Water from cistern $(+241 \mathrm{~m})$ to the Medaram tank (FRL $+230 \mathrm{~m}$ ) will move through gravity. To lift the huge amount of water during the monsoon high capacity of pumps $(6 \times 124.4 \mathrm{MW})$ will be installed in the pump house cavern.

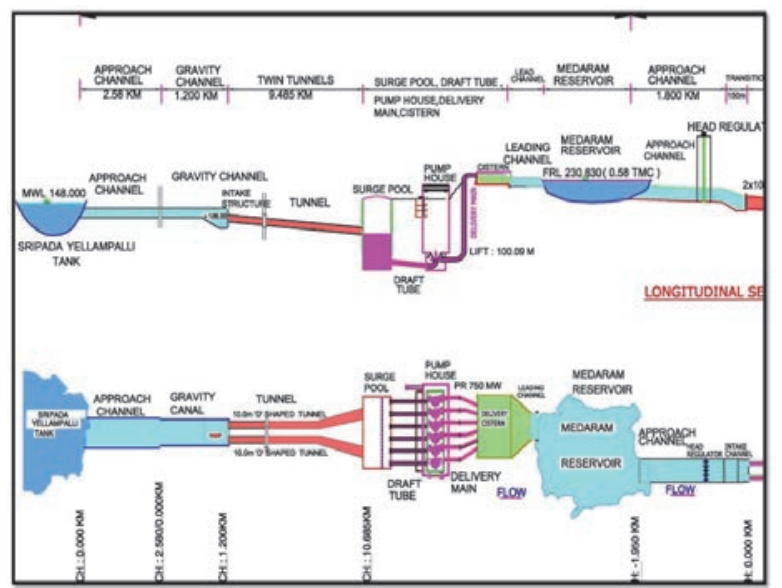

Fig.1. General layout map of Dr B R Ambedkar (PCSS) package-06 


\section{GeOlogy OF THE AREA}

The regional lithological units belong to NW-SE trending Karimnagar Granulite Terrane (KGT), supracrustal rocks of Peninsular Gneissic Complex (PGC) of Archean age [1,2]. Basics enclaves of older metamorphics occur within PGC granites at places which are mainly represented by pyroxinite/amphibolite [3]. Dolerite dykes are also emplaced into the main litho units at places. Medium to coarse grained, grey to pinkish grey granites, migmatite, gneiss and charnokites intruded by dolerite dyke and basic enclaves of Karimnagar Granulite Belt are exposed in the area [4,5]. The general stratigraphic sequence of the study area is given in Table 1 . The area is predominantly pediplain terrain dotted with inselberg, denudational and residual hillock developed over resistant granite rocks and small linear ridges of dolerite dykes [6].

Table1 Generalized Stratigraphic Sequence [7].

\begin{tabular}{|l|l|}
\hline $\begin{array}{l}\text { Quartz/pegmatitic veins (acid } \\
\text { intrusive) }\end{array}$ & \multirow{2}{*}{$\begin{array}{c}\text { Peninsular } \\
\text { Complex }\end{array}$} \\
\cline { 1 - 1 } Granodiorite & Gneissic \\
\cline { 1 - 1 } Biotite granite gneiss/ tonalite & $\begin{array}{c}\text { High } \\
\text { Supracrustals }\end{array}$ \\
\cline { 1 - 2 } Amphibolites/ pyroxene granulite & Grade \\
\cline { 1 - 2 } Banded magnetite quartzite/ quartzite \\
\hline
\end{tabular}

\section{GEOLOGICAL MAPPING AND ASSESSMENT OF RoCK} SUPPORT

Evaluation of right main tunnel (RMT) and left main tunnel (LMT) based on 3D geological mapping was done between chainages 8.298 and $9.865 \mathrm{~km}$ for cumulative length of $2.959 \mathrm{~km}$. This was done to suggest suitable measure for rock support and tunnel stability. The assessment of ' $Q$ ' $[8,9]$ for the encountered rock mass was done. Based on rock tunneling quality index ' $Q$ ' rock mass was categorized into fair, poor and very poor rock mass with occasional bands of good rock (Fig. 5 and 6 ). ISRM [10] classification was used for the characterization of rock mass into different weathering grade. Critical faces were mapped on 1:100 scale for giving necessary required rock support input and further excavation methodology.

The rock mass in RMT and LMT are intersected by four joints sets with random joint Table IIand III respectively. Basic enclaves generally recharge with water and whenever excavation was done in such type of tunnel media, stability problems were encountered. Basic-enclaves, grey graniteand garnetiferous granulite in the form of zones are the rock types encountered in the excavated reaches. The rock mass in RMT are falling under good $(4.78 \%)$, fair $(78.90 \%)$, poor $(14.39 \%)$ and very poor $(1.91 \%)$, rock classes. In the LMT rock mass categorized into good $(9.33 \%)$, fair $(75.57 \%)$ and poor $(15.08 \%)$. rock class. Support categories for the different rock mass class is given in Table IV.

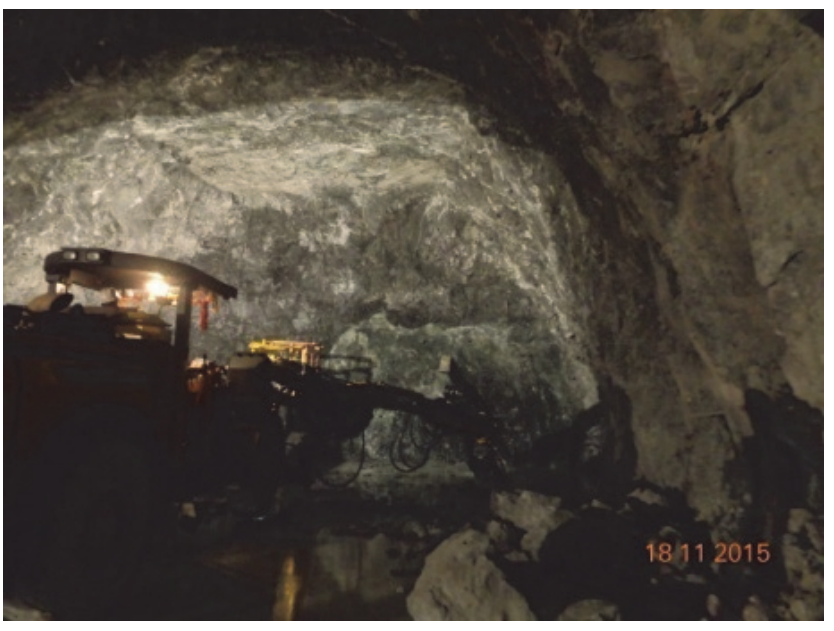

Fig.2. Metabasicenclaves exposed at chainage $9.100 \mathrm{~km}$ in LMT

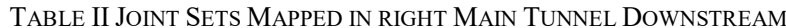

\begin{tabular}{|c|c|c|c|c|c|c|c|c|}
\hline \begin{tabular}{|l|} 
Joint \\
Set
\end{tabular} & $\begin{array}{l}\text { Dip direction/ } \\
\text { Dip Amount }\end{array}$ & \begin{tabular}{|l} 
Spacing \\
$(\mathrm{cm})$
\end{tabular} & $\begin{array}{l}\text { Persistence } \\
\text { (m) }\end{array}$ & Roughness* & $\begin{array}{l}\text { Aperture } \\
(\mathrm{mm})\end{array}$ & Infilling & \begin{tabular}{|l} 
Ground \\
Water
\end{tabular} & Remark \\
\hline $\mathrm{J} 1$ & $325-005 / 40-65$ & $16-60$ & $>20$ & $\mathrm{R} / \mathrm{I} / \mathrm{P}, \mathrm{SP}$ & Tight to 1 & Non softening material & $\mathrm{Dr}$ & $\begin{array}{l}\text { Prominent } \\
\text { joint }\end{array}$ \\
\hline $\mathrm{J} 2$ & $070-085 / 60-75$ & $20-60$ & $5-15$ & $\mathrm{R} / \mathrm{I} / \mathrm{P}, \mathrm{SP}$ & Tight to 1 & Non softening material & $\begin{array}{l}\text { Dripping/flo } \\
\text { wing }\end{array}$ & $\begin{array}{l}\text { Prominent } \\
\text { joint }\end{array}$ \\
\hline $\mathrm{J} 3$ & $245-250 / 30-40$ & $20-100$ & $>20$ & $\mathrm{R} / \mathrm{I} / \mathrm{P}, \mathrm{SP}$ & Tight to 2 & Non softening material & Dry & $\begin{array}{l}\text { Prominent } \\
\text { joint }\end{array}$ \\
\hline $\mathrm{J} 4$ & $160-190 / 35-50$ & $30-100$ & $>20$ & $\begin{array}{|ll|}\mathrm{R} / \mathrm{I} / \mathrm{P}, & \mathrm{S} / \mathrm{U}, \\
\mathrm{SP}\end{array}$ & Tight to 1 & Non softening material & Dry & $\begin{array}{l}\text { Prominent } \\
\text { joint }\end{array}$ \\
\hline $\mathrm{J} 5$ & $235-260 / 35-40$ & - & - & $\mathrm{R} / \mathrm{I} / \mathrm{P}, \mathrm{S} / \mathrm{U}, \mathrm{SP}$ & Tight to 1 & - & Dry & Random \\
\hline
\end{tabular}

TABLE IIIJOINT SETS MAPPED IN LEFT MAIN TUNNEL DOWNSTREAM

\begin{tabular}{|c|c|c|c|c|c|c|c|c|}
\hline $\begin{array}{l}\text { Joint } \\
\text { Set }\end{array}$ & $\begin{array}{l}\text { Dip direction/ } \\
\text { Dip Amount }\end{array}$ & \begin{tabular}{|l} 
Spacing \\
$(\mathrm{cm})$
\end{tabular} & \begin{tabular}{|l}
$\begin{array}{l}\text { Persistence } \\
(\mathrm{m})\end{array}$ \\
\end{tabular} & Roughness* & \begin{tabular}{|l} 
Aperture \\
$(\mathbf{m m})$
\end{tabular} & Infilling & $\begin{array}{l}\text { Ground } \\
\text { Water }\end{array}$ & Remark \\
\hline $\mathrm{J} 1$ & $330-355 / 40-65$ & $15-60$ & $>20$ & $\mathrm{R} / \mathrm{I} / \mathrm{P}, \mathrm{SP}$ & Tight to 1 & Non softening material & Dry & Prominent joint \\
\hline $\mathrm{J} 2$ & $070-090 / 45-70$ & $20-60$ & $5-15$ & $\mathrm{R} / \mathrm{I} / \mathrm{P}, \mathrm{SP}$ & Tight to 1 & - & $\begin{array}{l}\text { Dripping/flow } \\
\text { ing }\end{array}$ & Prominent joint \\
\hline $\mathrm{J} 3$ & $230-260 / 40-75$ & $20-100$ & $>20$ & $\mathrm{R} / \mathrm{I} / \mathrm{P}, \mathrm{SP}$ & Tight to 2 & Non softening material & Dry & Prominent joint \\
\hline $\mathrm{J} 4$ & $155-200 / 40-65$ & $15-60$ & $>20$ & $\mathrm{R} / \mathrm{I} / \mathrm{P}, \mathrm{S} / \mathrm{U}, \mathrm{SP}$ & Tight to 1 & Non softening material & Dry & Prominent joint \\
\hline J5 & $170-190 / 30-40$ & - & - & $\mathrm{R} / \mathrm{I} / \mathrm{P}, \mathrm{S} / \mathrm{U}, \mathrm{SP}$ & Tight to 2 & - & Dry & Random \\
\hline
\end{tabular}


TABLE IVSUPPORT CATEGORIES FOR THE DIFFERENT ROCK MASS ClASS

\begin{tabular}{|c|c|c|c|}
\hline Rock Class & $\begin{array}{l}\text { Tunneling } \\
\text { Quality Index } \\
\text { 'Q' }\end{array}$ & Support System & Remark \\
\hline Very Good & $\mathrm{Q}>40$ & Spot rock bolt only & \multirow{3}{*}{$\begin{array}{l}\text { Type of rock bolt HYSD Bars of Grade Fe } \\
415 \text { with cement and resin capsule grouted } \\
\text { and tensioned type. }\end{array}$} \\
\hline Good & $10<\mathrm{Q} \leq 40$ & $4.5 \mathrm{~m}$ long, $4.5 \mathrm{~m}$ spacing, $25 \mathrm{~mm}$ dia rock bolt & \\
\hline Fair & $4<\mathrm{Q} \leq 10$ & $\begin{array}{l}3 \& 5 \mathrm{~m} \text { long, } 1.5 \mathrm{~m} \text { spacing at crown, } 25 \mathrm{~mm} \text { dia rock } \\
\text { bolt, } 50 \mathrm{~mm} \text { thickness SFRS at crown and } 25 \mathrm{~mm} \text { at sides }\end{array}$ & \\
\hline \multirow[b]{2}{*}{ Poor } & \multirow{2}{*}{$\begin{array}{l}1<\mathrm{Q} \leq 4 \\
(2-4)\end{array}$} & ISMB $200 @ 1000$ mm c/c & \multirow{2}{*}{$\begin{array}{l}\text { The support system is designed for } \mathrm{Q}=2.29 \\
\text { and } \mathrm{Jr}=2.0 \text {. }\end{array}$} \\
\hline & & ISMB 300@1900 mm c/c & \\
\hline \multirow[b]{2}{*}{ Poor } & \multirow{2}{*}{$\begin{array}{l}1<\mathrm{Q} \leq 4 \\
(2-4)\end{array}$} & ISMB $200 @ 500$ mm c/c & \multirow{2}{*}{$\begin{array}{l}\text { The support system is designed for } \mathrm{Q}=2.29 \\
\text { and } \mathrm{Jr}=1.0 \text {. }\end{array}$} \\
\hline & & ISMB 300@950 mm c/c & \\
\hline \multirow[b]{2}{*}{ Poor } & \multirow{2}{*}{$\begin{array}{l}1<Q \leq 4 \\
(1-2)\end{array}$} & ISMB 200@400 mm c/c & \multirow{2}{*}{$\begin{array}{l}\text { The support system is designed for } \mathrm{Q}=1.38 \\
\text { and } \mathrm{Jr}=1.0 \text {. }\end{array}$} \\
\hline & & ISMB300@800 mm c/c & \\
\hline \multirow{2}{*}{ Very Poor } & \multirow{2}{*}{$0.1<\mathrm{Q} \leq 1$} & ISMB $200 @ 300$ mm c/c & \multirow{2}{*}{$\begin{array}{l}\text { The support system is designed for } \mathrm{Q}=0.77 \\
\text { and } \mathrm{Jr}=1.0 \text {. }\end{array}$} \\
\hline & & ISMB $300 @ 650$ mm c/c & \\
\hline
\end{tabular}

\section{ANTICIPATED ADVERSE GEOLOGY BASED ON BORE HOLES DATA}

In view of adverse geological condition encountered in RMT and LMT between 8.292 and $9.000 \mathrm{~km}$ tunnel reaches, investigations stage bore holes log data of balanced tunnels length drilled at 9.200, 9.350, 9.450, 9.600, $9.770 \mathrm{~km}$ were reviewed. After study of bore holes data it was observed that at chainage 9.200 and $9.450 \mathrm{~km}$ rock quality designation (RQD) value was reported nil. RQD values of chainages $9.350,9.600$ and $9.778 \mathrm{~km}$ were ranges between $10 \%$ and $40 \%$ indicating that excavation must be done carefully. As per subsurface data problematic zones were anticipated between 9.200 and $9.900 \mathrm{~km}$ tunnels reaches, where tunneling work will be delayed and man and machinery may not be utilized properly. Planning was made for avoid any delay and proper utilization of man and machineries. Probing map was prepared based on bore holesdata for the chainage between 9.100 and $9.910 \mathrm{~km}$.It was decided that probe holes, controlled blasting and immediate sealing shotcrete, spot bolts followed by design rock support will be done at earliest as possible in these anticipated tunnel reaches

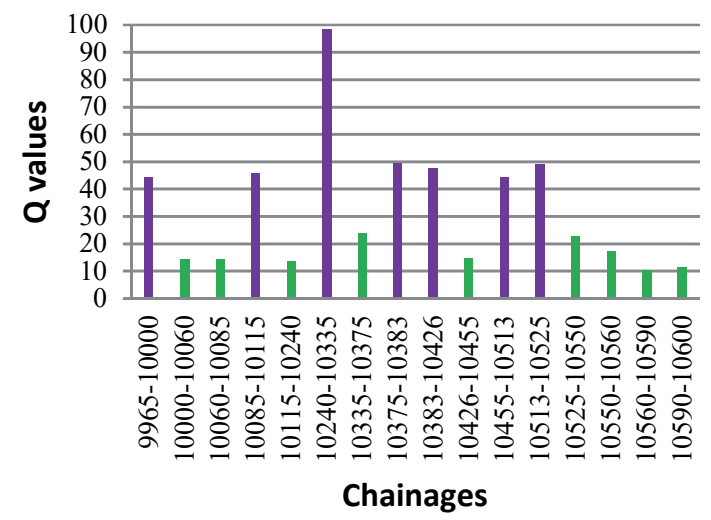

Fig.3. Graphical representation of Q map between 10.600 and $9.965 \mathrm{~km}$ of RMT

\section{MODIFICATION OF EXCAVATION PLAN BASED ON ANTICIPATED GEOLOGY}

Based on subsurface data information it was decided that excavation should be done towards upstream side from new proposed adit-3in view of anticipated adverse geology between chainage 9.200 and $9.900 \mathrm{~km}$. Based on detailed study, excavation plan was modified towards upstream in view of likely excavation progress delay for twin tunnels. Modification plan for excavation was suggested for chainage 10.500 to $9.915 \mathrm{~km}$ upstream and 10.500 to $10.600 \mathrm{~km}$ downstream tunnel reaches from the new proposed adit-3.

As per bore hole data of chainage $10.675 \mathrm{~km}$, anticipated geologywasgood/favorable rock media. A $565 \mathrm{~m}$ long multipurpose adit-3 was excavated to reach at the twin tunnels at $10.500 \mathrm{~km}$ and to enter in surge pool area. Adit-3 was excavated in the good to very good tunnel media except at the few locations where fair rock class was mapped in the form of weathered/altered and closely spaced joints in the form of bands. Graphical representation of ' $Q$ ' of 10.600 and 9.965 $\mathrm{km}$ reach is given in (Fig.3) -. Rock tunnel media intersected with one plus random to maximum two plus random joint sets and where rock tunneling quality index 'Q'ranges between10.24and98.5. RQD values ranges from82.0to $98.5 \%$. Excavation of twin tunnels werestarted from chainage 10.500 (junction) towards upstream i.e. $9.915 \mathrm{~km}$ and from 10.500 towards $10.600 \mathrm{~km}$ for excavation of twin tunnels and for surge pool entry. Excavation was completed within specified time frame as given by project management. Machinery and man power were utilized properly. Further excavation was done for entry in surge pool which was done with this modified excavation plan.

\section{VI.TunNeling Challenges AND METHOdology APPLIED IN ADVERSE TUNNEL REACHES}

During the excavation of advance right main tunnel (RMT) over break at chainage $8.452 \mathrm{~km}$ was recorded where seepage and metabasic were met during tunneling. Sudden over break after taken a blast at chainage $8.452 \mathrm{~km}$ which was finally reached upto $6.0 \mathrm{~m}$ length $\times 5 \mathrm{~m}$ (width) $\times 7 \mathrm{~m}$ (height) with seepage 160 liter/minute was recorded. Temporary and permanent rock support as soon as possible were completed and after crossing this cavity reach precautions were taken during further tunneling. Probe holes were done for critical/doubtful reaches. Fore polling was done after every 2 blasts and ensuring the overlapping in the critical poor/very poor tunnel reaches. When this problem encountered in right main tunnel (RMT), left main tunnel (LMT) was excavated 
upto $8.260 \mathrm{~km}$ and problem was anticipated well in advanced in LMT and precautions were taken.

Inview of poor and very poor rock mass encountered in RMT it was decided that precautions should be taken fromchainage $8.268 \mathrm{~km}$ with controlled blasting. After reaching at chainage $8.283 \mathrm{~km}$, three probe holes of $50 \mathrm{~mm}$ dia. and $12 \mathrm{~m}$ long were drilled and rock types were examined. Change in colour of backflow water (greenish black) and sudden change in penetration rate were observed at $8.0 \mathrm{~m}$ depth from face. During the drilling of right side probe hole, sudden gap was observed by Boomer operator. In view of changed in the colour of back flow water and penetration rate, forepoling with iron rod having $25 \mathrm{dia}$. and $5.5 \mathrm{~m}$ length at the crown level with $30 \mathrm{~cm}$ spacing up to the spring level was done. Some time the spacing of forepolling was slightly reduced in very critical tunnel reaches. At chainage $8.288 \mathrm{~km}$, basic enclaves with dripping condition was recorded and tunneling quality index ' $Q$ ' encountered at the tunnel reach fall under poor rock class.

Rock falling from left crown portion in LMT between chainage 9.060 .5 and $9.071 \mathrm{~km}$ was observed from already rock supported area. Rock falling was due to joints combination where ribs were erected in view of sitegeological conditions (Fig.7). Contact of metabasic enclaves with granite in the form of poor rock encountered at chainage $9.865 \mathrm{~km}$ reach which was excavated through adit-3in the metabasicsmedia with closely spaced joint in the form of crushed/loose formation where immediate sealing shotcrete followed by riberection upto $5 \mathrm{~m}$ area was completed. Facewas packedwith sand bags upto crown portion to avoid overbreak and sudden collapse. Sometime overbreak due to joint orientation was also observed in the some reaches where critical situation was faced for support and further excavation (Fig.4).

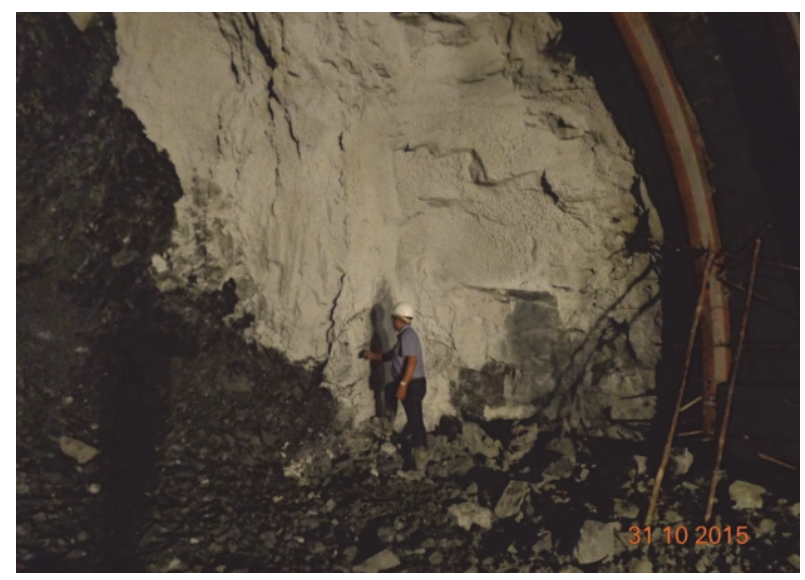

Fig.4. Contact zone between grey granite and metabasics enclaves at 9.865 $\mathrm{km}$ of LMT

Dripping to flowing condition was also recorded in various tunnel reaches where rock mass was found moderately to highly weathered and rock mass generally observed poor and rib were erected. Drainage holes were provided in the tunnel reach where seepage was encountered $>2$ liters/minute.

For the critical/doubtful tunnel reaches probe holes were done and if any change in backflow water and change in penetration rate observed during the drilling fore polling at the crown level was done to avoid any overbreak/sudden collapse. Fore polling were done with length of 3.5 to $5.0 \mathrm{~m}$ with 25 $\mathrm{mm}$ dia. rod for this purpose. In all the critical tunnel reaches immediate sealing shotcrete followed by spot bolt, pattern rock bolts \& shotcrete and rib were erected.

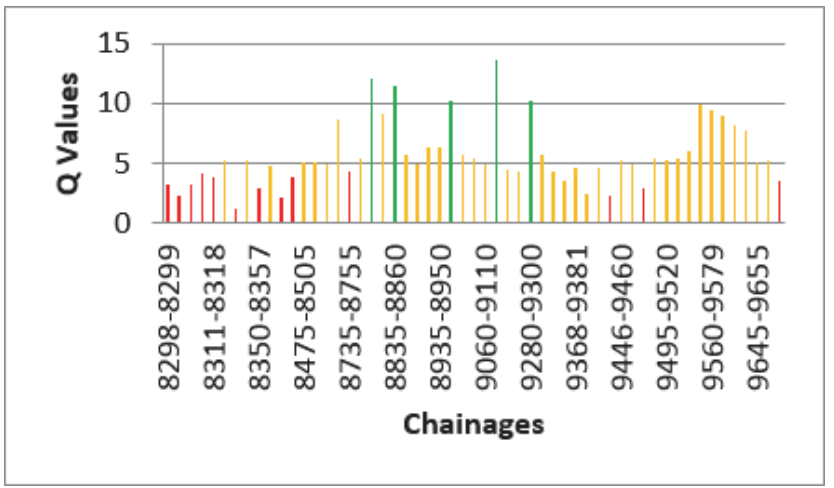

Fig.5. Graphical representation of Q map between 8.298 and $9.690 \mathrm{~km}$ of LMT

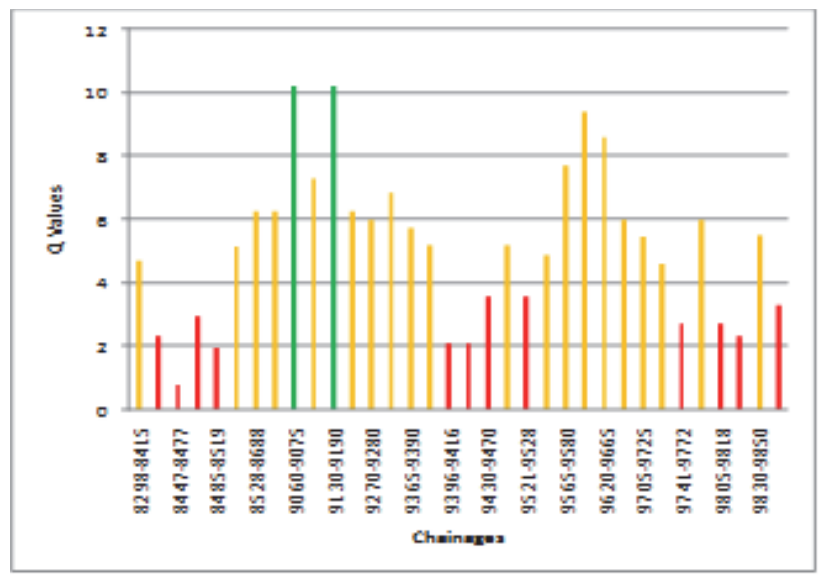

Fig.6. Graphical representation of Q map between 8.298 and $9.865 \mathrm{~km}$ of RMT

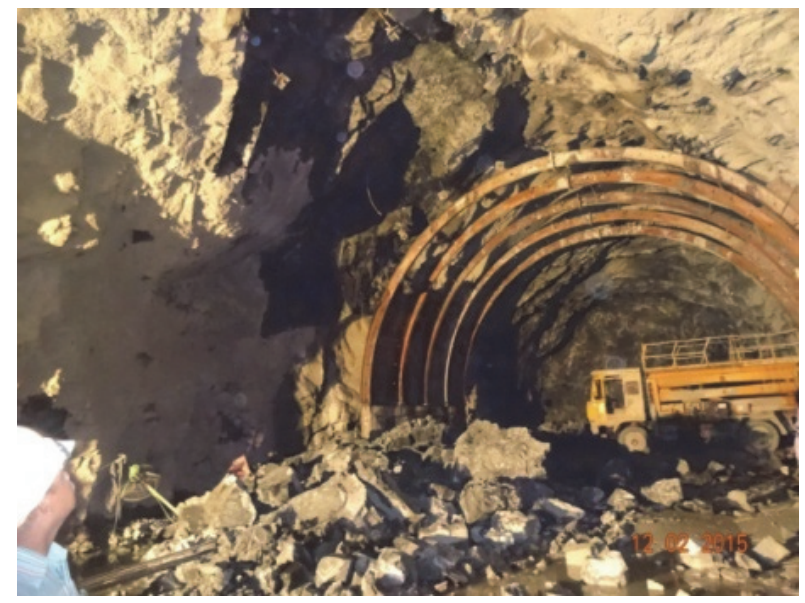

Fig.7. Rock falling between chainage 9.060 .5 and $9.071 \mathrm{~km}$ of LMT

Additional/longer rock bolts and shotcrete $50-100 \mathrm{~mm}$ thickness were done for the potential/wedge forming areas due 
to joint sets and continuity of joints at the different tunnel reaches in twin tunnels.

\section{CONCLUSION}

Granitic terrain is generally advisable tunneling media where chances of geological surprises and requirement of heavy rock support are less in comparison of Himalayan terrain. Sometimedue to this philosophy, during detailedinvestigation study for tunnel alignmentonly geomorphologic doubtful and contact zones of different geological formations are generally consideration for subsurface study. For this project about $3.146 \mathrm{~km}$ twin tunnels alignment was not properly investigated due to the above mentioned philosophy. In these reaches bore holes were drill at the rock ledge (middle rock mass) of the twin tunnels. Projecting Q-values for the similar chainages in various locations were not matching with the actual values. Tunnel progress was delayed due to adverse geological condition during tunneling work. Advance modification planning was done otherwise it would have more fiscal losses. All these type of things can be avoided through proper Detailed Project Report stage investigations.

Granitic terrain is mostly good tunneling media but the intrusive/adverse geological conditions make it problematic where underground excavation and support system is time taking process. Adverse geological probability increased with respect of tunnel length. In such type of longer tunnels more subsurface data needs to be interpreted for the selection of safe tunneling alignment. Tunnel alignment needs to be decided based on subsurface data rather than based on rock type. Tunnel diameter can be minimized and number of tunnels can be increased as per the site geological conditions.

As per site geological condition additional support in view of joint sets can be provided to avoid overbreak and smooth tunneling work. Software based wedge analysis also helpful study in view of deep effect of joint combination on the rock mass.

Necessary modification on excavation plan and support design is required if some doubtful/adverse geological features are anticipate in ahead tunnel reaches in the rock mass. Twin tunnels were supported with heavysteel ribs for the encountered rock class based on tunneling quality index ' $Q$ ' for poor and very poor rock tunnel reaches.

Overbreaks due to combination of joints was recorded. In general poor and very poor rock chainages are very difficult to anticipate without probe hole techniques but in this project site based on jointnature/orientation, $25 \mathrm{~m}$ in advanced rock mass was anticipated.

Between chainage 8.298 and $9.865 \mathrm{~km}$ in RMT and 8.298 and $9.690 \mathrm{kmin}$ LMT rock class falls in very poor $1.01 \%$, poor $14.71 \%$, fair $77.34 \%$ and good rock $6.92 \%$. Terrain does not give the actual idea about the rock mass conditions. With the help of subsurface exploration rock mass can be categorized in a better way. Planning for bore holes should be done on the tunnel alignment. For twin tunnels it can not be on the rock ledge, but should be for both the tunnels. Proper investigations can save crores of rupees and time.For this project advance planning for the modification in excavation plan was done.Timely supporting of adverse geological reacheswith some delay was done but without loss or injury of manpower and machinery.

\section{ACKNOWLEDGEMENTS}

Authors are thankful to Director NIRM for the permission to send the manuscript for publication, encouragement and technical guidance. This paper is prepared from the project work sponsored by NECL, so we sincerely thank the Management of NECL for the same.

\section{REFERENCES}

[1] D. Prakash, and I.N. Sharma, "Metamorphic evolution of Karimnagar granulite terrane, Eastern Dharwar Craton, South India," Geological Magazine, vol. 48, pp 112-132, 2011.

[2] P.K. Raman, and V.N. Murthy, "Geology of Andhra Pradesh," Geological Society of India, pp 244, 2012.

[3] T. Rajesham, Y.J. Bhaskar Rao, and K.S. Murty, "The Karimnagar granulite terrrain - A new sapphirine bearing granulite province, south India," Journal Geological Society of India, vol. 41, pp 51-59, 1993.

[4] I.N. Sharma and D. Prakash, "Occurrence of kornerupine-bearing granulite from Karimnagar,” Andhra Pradesh, Current Science, vol. 91, pp 678- 683, 2006.

[5] Anjan. Som, , M. Sai Baba, A.V. Jeyagopal, K. Shobhita, , R. Mohanty and P. B. Maithani, "Occurrence of Uranium in meta-sedimentary enclaves within basement granite, near Peddur and Kottur, Karimnagar District, Andhra Pradesh," Journal Geological Society of India, vol. 76, pp 247-250, 2010.

[6] G.J.S., Prasad, and B.P., Rawat, "Report on feasibility stage geotechnical investigation for twin tunnel from the SripadaYellampally reservoir to Nandimedaram tank, Dr. B.R. AmbedkarPranahitha ChevellaSujalaShravanthi package-6 Karimnagar District," Andhara Pradesh. Unpublished Geological Survey of India, Southern Region, Hyderabad report, FS 2008-09 \& 2010-12, 2011.

[7] T. Kameswara Rao, "Petrological and geochemical studies of high gradesupracrustal rocks and associated granite and migmatite gneissic complex in parts of Karimnagar District," A.P. Rec. Geological. Survey of India, Vol.122, pp.433-436. 1989.

[8] N. Barton, R. Lien, and J. Lunde, "Engineering classification of rock masses for the design of tunnel support," Rock Mechanics, vol. 6 (4), pp 189-236, 1974.

[9] N. Barton, F. Loest, R. Lien, and J. Lunde, "Application of the Q system in design decisions concerning dimensions and appropriate support for underground installations," International Conference on Sub-surface Space, Rock Store, Stockholm. Vol. II, pp 553-561, 1980.

[10] ISRM,"Suggested method for the quantitive description of discontinuities in rock mass," International Journal of Rock Mechanics and mining science \&Geomechanics. (Abstrct), Pergamon, v.15 (6), pp 319-368, 1978. 